\title{
Studies on a murine model of congenital toxoplasmosis: vertical disease transmission only occurs in BALB/c mice infected for the first time during pregnancy
}

\author{
C. W. ROBERTS and J. ALEXANDER* \\ Department of Immunology, The Todd Centre, 31 Taylor St, University of Strathclyde, Glasgow G4 ONR
}

(Received 7 May 1991; revised 24 fuly 1991; accepted 31 fuly 1991)

\begin{abstract}
SUM MARY
The incidence of congenital toxoplasmosis was determined by an ELISA in the litters of BALB/c mice which had been infected 8 weeks before mating, on day 12 of pregnancy, or on both these occasions. Of those mice given the infection for the first time on day 12 of pregnancy, 5 out of 6 gave birth to infected litters with approximately $50 \%$ of the individuals in each litter being infected. BALB/c mice which had been infected 8 weeks before mating did not give birth to infected litters, even if they were reinfected on day 12 of pregnancy. Following infection BALB/c mice were found to harbour significantly fewer tissue cysts than the congenic $\mathrm{H}-2$ derivative BALB/K strain. However, chronically infected BALB/K mice also failed to produce infected litters, indicating that tissue cyst burden in the dam did not influence congenital infection at least on the BALB background. This study demonstrates that BALB/c dams chronically infected with Toxoplasma gondii, have immunity capable of protecting their embryos from congenital infection, even if the dams are reinfected during pregnancy. Our results demonstrate that the BALB/c mouse can be used as a model of human or ovine congenital $T$. gondii infection suitable for testing putative vaccines.
\end{abstract}

Key words: congenital infection, ELISA, immunity, Toxoplasma gondii, BALB/c.

\section{INTRODUCTION}

Toxoplasma gondii is a coccidian parasite of felids and has, as intermediate hosts, many warm-blooded animals, including mammals and birds (reviewed by Jackson \& Hutchison, 1989). An intermediate host may become infected either through the ingestion of infected meat or by ingesting faecal material from infected cats. Non-congenitally acquired toxoplasmosis in the immunocompetent human host is commonly asymptomatic, although flu-like symptoms are common at the onset of infection. Congenital infection, which occurs if a mother is infected for the first time during pregnancy, is often serious, resulting in abortion or severe neurological and ophthalmological pathology (reviewed by Hughes 1985). Congenitally acquired toxoplasmosis is not only of great medical concern but is also of enormous economic importance as this disease is the second major cause of ovine abortion in the United Kingdom (Linklater \& Dyson, 1979).

Obviously the development of a vaccine which protects the adult and consequently reduces the incidence of congenital disease would be highly desirable. For this reason the development of a suitable laboratory model of congenital toxoplasmosis is essential to test the efficacy of putative vaccines. Such a model system has been studied in

* Reprint requests to Dr J. Alexander. this laboratory, using outbred mice and has proven useful in studying ophthalmological, behavioural and neurological sequelea (Hay et al. 1981, 1985; Hutchison et al. 1982; McMenamin et al. 1986; Dutton et al. 1986). However, the value of this model for immunological studies or vaccine design has never been assessed; indeed to analyse, dissect and characterize the nature of protective immunity as well as guaranteeing reproducibility of results, it is essential that the disease model should comprise the use of inbred mice. The suitability of a murine model of congenital infection could, however, be questioned due to the apparent differences in the disease transmission patterns between the mouse

Table 1. Experimental protocol

\begin{tabular}{|c|c|c|c|c|c|}
\hline & \multicolumn{5}{|c|}{ Treatment } \\
\hline & Week 8 & Day 0 & Day 12 & Week 3 & Week 11 \\
\hline Group 1 & $\begin{array}{l}5 \text { Cysts } \\
\text { orally }\end{array}$ & Mate & - & $\begin{array}{l}\text { Foster } \\
\text { pups }\end{array}$ & Bleed pups \\
\hline Group 2 & - & Mate & $\begin{array}{l}20 \text { Cysts } \\
\text { orally }\end{array}$ & $\begin{array}{l}\text { Foster } \\
\text { pups }\end{array}$ & Bleed pups \\
\hline Group 3 & $\begin{array}{l}5 \text { Cysts } \\
\text { orally }\end{array}$ & Mate & $\begin{array}{l}20 \text { Cysts } \\
\text { orally }\end{array}$ & $\begin{array}{l}\text { Foster } \\
\text { pups }\end{array}$ & Bleed pups \\
\hline Group 4 & - & Mate & - & $\begin{array}{l}\text { Foster } \\
\text { pups }\end{array}$ & Bleed pups \\
\hline
\end{tabular}




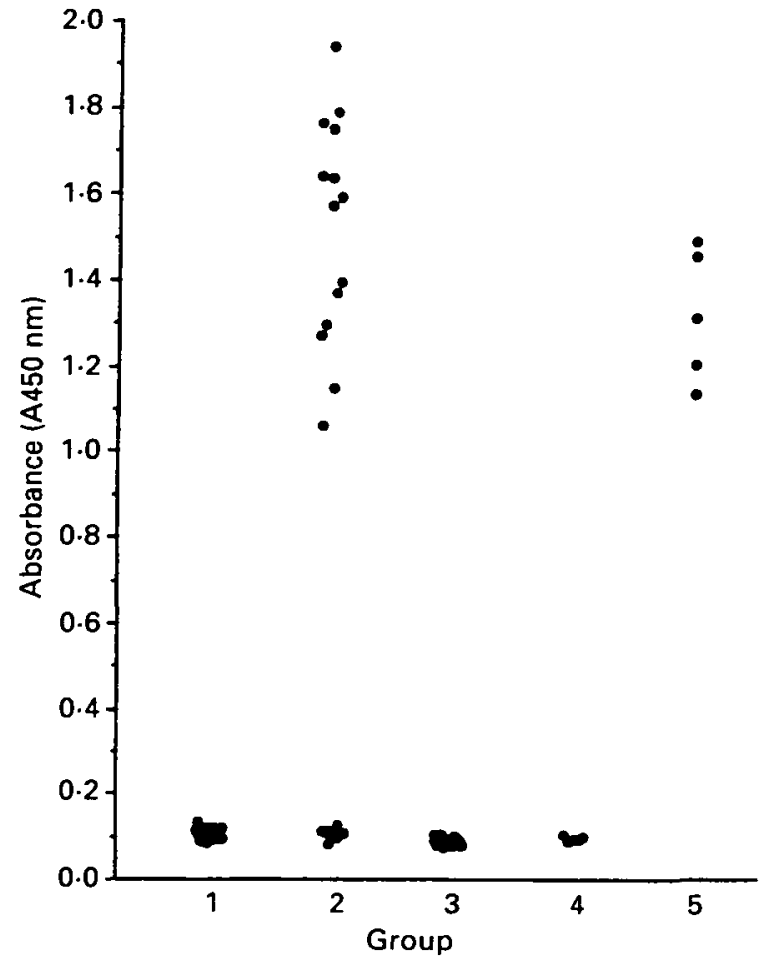

Fig. 1. Absorbance at $450 \mathrm{~nm}$ of plasma samples tested by ELISA, from the offspring of BALB/c dams infected, either 8 weeks prior to mating (1), on day 12 of pregnancy (2), or 8 weeks prior to mating and on day 12 of pregnancy (3). Normal uninfected adult BALB/c mice (4) and BALB/c mice infected as adults (5).

Offspring were bled at 8 weeks of age and adults were bled 8 weeks post-infection.

and humans or ovids. The literature would indicate that while vertical transmission through successive generations is the normal situation in mice (Beverley, 1959 ) it is not in either humans (Cook, 1990) or ovids (Beverley \& Watson, 1971) where only infection for the first time during pregnancy results in congenital infection. These differences might suggest that mice would make poor substitutes for studying immunoprophylaxis of human or ovine congenital disease. The following study was therefore undertaken to determine whether chronically $T$. gondii-infected $\mathrm{BALB} / \mathrm{c}$ mice produced healthy, disease-free litters and whether a prior infection decreased the likelihood of congenital infection following a second exposure during pregnancy. The results would indicate the usefulness of this model for vaccine studies.

MATERIALS AND METHODS

\section{Mice}

Inbred $\mathrm{BALB} / \mathrm{c}, \mathrm{BALB} / \mathrm{K}$ and $\mathrm{C} 57 \mathrm{BL} / 10$ mice were bred and maintained in this laboratory under conventional conditions. Mice were used when 8-10 weeks old unless otherwise stated.

\section{Infections}

The brains from mice, infected 3 months previously with the RRA (Beverley) strain of $T$. gondii, were removed, placed in $2 \mathrm{ml}$ of saline and passed 6 times through a number 21 gauge needle. Then $30 \mu \mathrm{l}$ of each brain suspension were placed on a glass microscope slide and mounted with a cover-slip and the number of cysts determined microscopically by scanning the entire preparation under $100 \times$ magnification. Mice were infected orally with 5 cysts, either 8 weeks prior to mating, or with 20 cysts on day 12 of pregnancy or on both these occasions with 5 and then 20 cysts respectively. Other mice were not inoculated and acted as prima gravid age-matched controls. The experimental protocol is summarized in Table 1. Infections were confirmed in all cases by the detection of anti- $T$. gondii IgG plasma samples taken 8 weeks after administration of infective brain homogenate.

\section{Mating}

Virgin female mice, uninfected or with an 8 week chronic infection were housed 3 to a cage with 1 male. Mice were inspected daily for the presence of vaginal plugs and the day of discovery designated day 0 . As soon as possible after birth litters were fostered to uninfected lactating dams, to avoid possible infection through lactation.

\section{Detection of congenital infection}

(i) ELISA. To obtain plasma samples the offspring were bled via the tail vein when they were 8 weeks old. Plasma was separated by centrifugation and used at 1 in 2000 dilution in the ELISA test.

Antigen was prepared as follows. Tachyzoites, grown in the peritoneum of cotton rats were washed 3 times in saline and resuspended in hypotonic buffer consisting of $10 \mathrm{~mm}$ Tris- $\mathrm{HCl}, 2 \mathrm{~mm}$ EDTA, pH 7.8, with $50 \mu \mathrm{M} N$-p-tosyl-L-lysine chloromethylketone (TLCK) and $15 \mu \mathrm{M}$ leupeptin (Sigma). After sitting on ice for $15 \mathrm{~min}$, the parasites were disrupted in a Braun homogenizer and centrifuged at $10000 \mathrm{~g}$ for $60 \mathrm{~min}$ at $4^{\circ} \mathrm{C}$. The supernatant fraction was collected and the protein concentration determined by the Bradford Assay (Bradford, 1976).

The ELISA was performed by a modification of the procedure described by Voller et al. (1976). Each well of a 96-well microtitre plate was coated overnight at $4^{\circ} \mathrm{C}$, with $1 \mu \mathrm{g}$ of supernatant antigen in $0.02 \mathrm{M}$ Tris-HCl buffer ( $\mathrm{pH} \mathrm{9.0).} \mathrm{After} \mathrm{incubation}$ for $1 \mathrm{~h}$ with the diluted test plasma, plates were washed 3 times and rat anti-mouse IgG horseradish peroxidase conjugate (Jackson Laboratories, Stratech Scientific Ltd.) was applied. Following further washes binding was visualized with tetramethyl benzidine in a sodium acetate buffer containing 
Table 2. The incidence of congenital toxoplasmosis infection and mean number of pups in litter of $\mathrm{BALB} / \mathrm{c}$ mice

\begin{tabular}{lllll}
\hline \hline & Time of infection of the dams & $\begin{array}{l}\text { No. of infected } \\
\text { litters/total litters }\end{array}$ & $\begin{array}{l}\text { No. of infected } \\
\text { pups/total born } \\
\text { pups born }\end{array}$ & $\begin{array}{l}\text { Mean no. of } \\
\text { pups/litter }\end{array}$ \\
\hline Group 1 & 8 weeks before mating* & $0 / 9$ & $0 / 50$ & $5 \cdot 5 \pm 0 \cdot 4$ \\
Group 2 & Day 12 of pregnancy & $5 / 6$ & $14 / 36$ & $6 \cdot 0 \pm 0 \cdot 4$ \\
Group 3 & 8 weeks before mating* and on day 12 of pregnancy $\dagger$ & $0 / 9$ & $0 / 47$ & $5 \cdot 2 \pm 0 \cdot 7$ \\
Group 4 & Age-matched uninfected controls & $0 / 10$ & $0 / 40$ & $4 \cdot 0 \pm 0 \cdot 63$ \\
Group 5 & Stock BALB/c uninfected & $0 / 99$ & $0 / 836$ & $8 \cdot 4 \pm 0 \cdot 25$ \\
\hline \hline
\end{tabular}

* 5 cysts inoculated orally.

+20 cysts inoculated orally.

$\mathrm{H}_{2} \mathrm{O}_{2}$ and the reaction stopped with $10 \% \mathrm{H}_{2} \mathrm{SO}_{4}$. Absorbance was read at $450 \mathrm{~nm}$ on a Titertek Multiscan plate reader. Values of greater than 3 times the negative control were taken as positive, although positives were generally more than 10 times the control value.

\section{(ii) Subinoculation into C57BL/10 mice}

Offspring were sacrificed when they were 9 weeks old and their brains were placed in $1 \mathrm{ml}$ of $0.9 \%$ saline and passed 6 times through a number 21 gauge needle. C57BL/10 mice were injected intraperitoneally with $0.02 \mathrm{ml}$ of brain suspension. Four weeks later the C57BL/10 mice were sacrificed and $30 \mu \mathrm{l}$ of brain suspension were examined microscopically for the presence of tissue cysts as described previously.

\section{RESULTS}

The incidence of congenital toxoplasmosis in the various experimental groups is summarized in Fig. 1 and Table 2. An infected individual was one that had a significant specific $T$. gondii antibody response as determined by ELISA 8 weeks after birth (Fig. 1). As clearly demonstrated there was no ambiguity in the specific antibody levels between infected and non-infected individuals. Disease-positive individuals displayed an extremely high absorbance value compared with non-infected mice. Of $9 \mathrm{BALB} / \mathrm{c}$ mice infected with 5 cysts 8 weeks prior to mating, none of their offspring were found to be infected. Five of 6 litters from BALB/c mice infected for the first time on day 12 of pregnancy did have infected individuals. Out of a total of 28 surviving pups from this group, 14 were infected. One pup in this group had bilateral cataracts 8 weeks after parturition. No congenital infections were detected, however, in the 47 pups born to the $9 \mathrm{BALB} / \mathrm{c}$ dams which had been infected with $T$. gondii 8 weeks prior to mating and reinfected on day 12 of pregnancy.

All of the mice with elevated specific anti- T. gondii IgG levels were found to have cysts in their brains at death and brain homogenates from these mice were also infective to naive recipients. Cysts were totally absent from the brains of antibody-negative individuals and brain homogenates from antibody-negative pups also failed to infect $T$. gondii-susceptible C57BL/10 mice. This clearly demonstrates that the presence of $T$. gondii-specific $\operatorname{IgG}$ is a reliable indicator of infection.

The mean number of pups in each litter during these experiments was significantly smaller $(P<$ 0.01 , Student's $t$-test) than those we have come to expect from normal breeding stock BALB/c mice (Table 2). However, the number of offspring in litters born to mice with a $T$. gondii infection, either chronic or acute, was not significantly different from age-matched prima gravid control mice. Due to rejection after fostering the incidence of neonatal death was high in all groups (14.3\% in total). Whether the dam was infected with $T$. gondii before or after pregnancy did not significantly alter pup mortality which was of a similar order in the pups of age-matched, non-infected dams.

Chronically infected BALB/K mice have significantly more cysts in their brains $(3120 \pm 766)$ than $\mathrm{BALB} / \mathrm{c}$ mice $(193 \pm 58)$ infected for a similar time period (8 weeks). Nevertheless, the litters of 7 $\mathrm{BALB} / \mathrm{K}$ mice (34 pups in total) infected 8 weeks before pregnancy with $T$. gondii were found to be completely free of infection as measured both by ELISA and inoculation of brain tissue into susceptible C57BL/10 mice. Post-mortem examination of the brain of the BALB/K mothers demonstrated heavy tissue cyst burdens. Approximately $50 \%$ of the offspring of BALB/K mice infected for the first time on day 12 of pregnancy were infected. The results with this strain are therefore similar to those we have obtained using BALB/c mice and vertical disease transmission is limited to infection during pregnancy.

In these experiments $\mathrm{BALB} / \mathrm{c}$ mice were infected on day 12 after mating. In a previous experiment when $10 \mathrm{BALB} / \mathrm{c}$ mice were infected orally with 20 tissue cysts 7 days after mating, 5 mothers died 
before giving birth, 3 did not litter and were found on post-mortem examination to have resorbed their embryos and 2 litters were aborted. Of 10 infected on day 12 after mating all littered, most pups survived and approximately $50 \%$ were infected as determined by ELISA, a result similar to that described above.

\section{DISCUSSION}

This study clearly demonstrates that chronically infected $\mathrm{BALB} / \mathrm{c}$ mice do not allow vertical disease transmission and congenital infection in these mice only occurs if the mother is infected for the first time during pregnancy. Therefore, vertical disease transmission is limited to one generation in this mouse strain. This finding contrasts with numerous other studies on congenital toxoplasmosis using rats (Wildfuhr, 1954), mice (Beverly, 1959), rats and mice (Remington, Jacobs \& Melton, 1961) and mice and hamsters (De Roever Bonnet, 1969), where vertical transmission has been demonstrated in chronically infected animals from generation to generation. These early studies used outbred animals, or in the case of Remington et al. (1961) NIH mice. Our observations are based primarily on the $B A L B / c$ inbred strain and its $\mathrm{H}-2$ congenic, $\mathrm{BALB} / \mathrm{K}$, derivative.

Using the laboratory model originally described by Hay et al. (1981) infection of outbred mice with $T$. gondii on day 12 of pregnancy is the most effective time at which to produce infected pups. We have confirmed these results using inbred BALB/c mice and our additional observations indicate that infection earlier in pregnancy results in resorption or abortion. Litters are routinely fostered onto lactating dams as previous reports indicated that $T$. gondii can be transmitted via lactation (Eichenwald, 1948). Litters are tested for $T$. gondii-specific IgG at 8 weeks of age in order to ensure that maternal antibody is not measured and false positives obtained. However, our unpublished observations indicate that $T$. gondii-specific antibody is not readily detectable in the plasma of offspring until this time. It has, in fact, recently been demonstrated that the offspring of chronically infected mice show a delayed antibody response to a $T$. gondii challenge infection which can last for as long as 8 weeks (Suzuki \& Kobayashi, 1990), thus indicating the effectiveness of our experimental protocol.

The likelihood is that the maternal antibody against $T$. gondii inhibits the onset of immunity in the infected pups. A positive anti- $T$. gondii ELISA at 8 weeks of age shows $100 \%$ correlation with $T$. gondii infection as detected by subinoculation of brain tissue to naive mice and confirmation by microscopical examination.

It is well documented that different mouse strains exhibit different levels of resistance to $T$. gondii (Williams, Grumet \& Remington, 1978; Johnson,
1984; Jones \& Erb, 1985; McLeod et al. 1989). $\mathrm{BALB} / \mathrm{c}$ mice infected intraperitoneally with the $\mathrm{Pe}$ strain are fairly resistant and harbour few cysts in their brain, contrasting with C57BL/10 mice which harbour many (Jones $\&$ Erb, 1985). In this laboratory we have observed a similar pattern when infecting orally with the RRA strain; $B A L B / c$ mice have moderate mortality and harbour few cysts, whereas C57BL/10 mice have many cysts accompanied with severe wasting and eventual death. Given the stark differences in the disease pattern of non-congenitally acquired toxoplasmosis between different inbred strains of mice, it would not be surprising if there was also a difference in the transmission of congenital disease. Intuitively it would be anticipated that those mice harbouring large numbers of cysts would be more likely to allow vertical disease transmission than those harbouring few cysts. However, no congenital transmission was detected in the litters of chronically infected $\mathrm{BALB} / \mathrm{K}$ mice, although the mothers themselves were found to have extremely high cyst counts.

The number of offspring born in a litter to all $T$. gondii-infected dams did not differ significantly from non-infected age-matched prima gravid mice but, was significantly reduced compared with stock $\mathrm{BALB} / \mathrm{c}$ mice from our breeding colony. Stock $\mathrm{BALB} / \mathrm{c}$ mice are mated for the first time when 8-10 weeks old, whereas the experimental and control groups were mated when 16-18 weeks old. Fertility obviously drops dramatically in this mouse strain with age.

Previous studies have also indicated that a degree of immunity can be conferred in a mouse model of congenital $T$. gondii infection (McLeod et al. 1988). In this case immunization was achieved by introducing a temperature-sensitive mutant intra-intestinally into Swiss mice before pregnancy. The incidence of infection in litters born to mice treated in this way was $64 \%$, whereas $94 \%$ of litters born to nonimmunized animals were infected. In contrast, we find that $\mathrm{BALB} / \mathrm{c}$ mice infected before pregnancy with the cyst-forming RRA strain, are resistant to such a degree that none of their offspring become infected. The advantages of the disease model reported in this paper are self-evident.

Finally, except in the case of immunodepressed mothers (Desmonts, Couvreur \& Thulliez, 1990) it has been the general consensus that congenital infection in humans or sheep only occurs if the mother acquires the infection for the first time during pregnancy. This indicates that a vaccine generating sufficient protective immunity could prevent congenital infection. Our results indicate that the BALB/c mouse can be used as a model of human or ovine congenital toxoplasmosis suitabie for testing new vaccines and chemotherapeutic agents as well as identifying those elements of the immune system promoting disease resistance. 
This project received funding from Scottish Hospital Endowments Research Trust and the Agriculture and Food Research Council.

\section{REFERENCES}

BEVERLEY, J. K. A. (1959). Congenital transmission of toxoplasmosis through successive generations of mice. Nature, London 183, 1348-9.

BEVERLEY, J. K. A. \& WATSON, W. A. (1971). Prevention of experimental and naturally occurring ovine abortion due to toxoplasmosis. Veterinary Record 88, 39-41.

BRADFORD, M. M. (1976). A rapid and sensitive method for the quantitation of microgram quantities of protein utilising the principle of protein dye binding. Analytical Biochemistry 72, 248-54.

соOK, G. C. (1990). Toxoplasma gondii infection: a potential danger to the unborn fetus and AIDS sufferer. Quarterly fournal of Medicine 74, 273-319.

DE ROEVER-BONNET, H. (1969). Congenital toxoplasmosis. Tropical and Geographical Medicine 21, 443-50.

DESMONTS, G., COUVREUR, J. \& THULL.IEZ, P. (1990). Congenital toxoplasmosis. Five cases with mother to child transmission of pre-pregnancy infection. Presse Medicale 19, 1445-9.

DUtTon, G. N., MCMENamin, P. G., HaY, J. \& Cameron, s. (1986). The ultrastructural pathology of congenital murine toxoplasmic retinochoroiditis. Part II : the morphology of the inflammatory changes.

Experimental Eye Research 43, 545-60.

EICHENWALD, H. (1948). Experimental toxoplasmosis.

Transmission of the infection in utero and through the milk of lactating female mice. American Fournal of Diseases of Children 76, 307-15.

HAY, J., HUTCHISON, W. M., LEE, W. R. \& SIIM, J. c. (1981). Cataract in mice congenitally infected with Toxoplasma gondii. Annals of Tropical Medicine and Parasitology 75, 455-7.

hay, J., Graham, D. I., hUTChison, W. M., LeE, W. R. \& SIIM, J. C. (1985). Meningo-encephalitis accompanying retinochoroiditis in a murine model of congenital toxoplasmosis. Annals of Tropical Medicine and Parasitology 79, 21-9.

HUGHES, H. P. A. (1985). How important is

Toxoplasmosis? Toxoplasmosis a neglected disease. Parasitology Today 1, 41-4.
HUTCHISON, W. M., HAY, J., LEE, W. R. \& SIIM, J. C. (1982). A study of cataract in murine congenital toxoplasmosis. Annals of Tropical Medicine and Parasitology 76, 53-70.

JACKSON, M. H. \& HUTCHISON, w. M. (1989). The prevalence and source of Toxoplasma infection in the environment. Advances in Parasitology 28, 55-86.

JOHNSON, A. M. (1984). Strain-dependent, route of challenge-dependent murine susceptibility to toxoplasmosis. Zeitschrift für Parasitenkunde 70, 303-9.

JONES, T. C. \& ERB, P. (1985). H-2 complex linked resistance in murine toxoplasmosis. Yournal of Infectious Diseases 151, 739-40.

LINKLATER, K. A. \& DYSON, D. A. (1979). Field studies on enzootic abortion of ewes in South East Scotland. Veterinary Record 105, 387-9.

MCLEOD, R., FRENKEL, J. K., ESTEES, R. G., MACK, D. G., EISENhaueR, P. B. \& GiBorI, G. (1988). Subcutaneous and intestinal vaccination with tachyzoites of Toxoplasma gondii and acquisition of immunity to peroral and congenital challenge. Fournal of Immunology 140, 1632-7.

MCLEOD, R., SKAMENE, E., BROWN, C. R., EISENHAUER, P. B. \& MACK, D. G. (1989). Genetic regulation of early survival and cyst number after peroral Toxoplasma gondii infection of $\mathrm{A} \times \mathrm{B} / \mathrm{B} \times \mathrm{A}$ recombinant inbred and B10 congenic mice. Fournal of Immunology 143 $3031-4$.

MCMENAMiN, P. G., DUTTON, G. N., HAY, J. \& CAMERoN, s. (1986). The ultrastructural pathology of congenital murine toxoplasmic retinochoroiditis. Part I: the localisation and morphology of Toxoplasma cysts in the retina. Experimental Eye Research 43, 529-43.

REMINGTON, J. S., JACOBS, L. \& MELTON, M. L. (1961). Congenital transmission of toxoplasmosis from mother animals with acute and chronic infections. Journal of Infectious Diseases 108, 163-73.

SUZUKI, Y. \& KOBAYASHI, A. (1990). Induction of tolerance to Toxoplasma gondii in newborn mice by maternal antibody. Parasitology Research 76, 424-7.

VOLLER, A., BIDWELL, D. E., BARTLETT, A., FLECK, D. G., PERKINS, M. \& OLDEHIN, B. (1976). A microplate enzyme-immunoassay for Toxoplasma antibody. Fournal of Clinical Pathology 29, 150-3.

wildfuHR, G. (1954). Toxoplasmose. Jena: Gustav Fischer.

WILLIAMS, D. M., GRUMET, F. C. \& REMINGTON, J. S. (1978). Genetic control of murine resistance to Toxoplasma gondii. Infection and Immunity 19, 416-20 